They promise to be particularly flexible and thus suitable for small batch production.

\section{Brain Drain, Both Ways}

THe Meteorological Office announced with considerable pleasure this week that Professor Raymond Hide, professor of geophysics and physics at the Massachusetts Institute of Technology, will be joining it in September of this year. Professor Hide graduated from the University of Manchester in 1950, took his doctorate at Cambridge in 1953, and became a lecturer at the University of Newcastle. He was appointed a full professor at MIT in 1961 at the early age of 32, and is well known for his work on fluid motions in the atmosphere, the Earth's core and the atmosphere of Jupiter. A special senior post has been established in the Meteorological Office for Professor Hide, who will be in charge of a new laboratory of geophysical fluid dynamies.

Dr John Napier of the University of London is going the other way across the Atlantic. $\mathrm{He}$ has been appointed by the Smithsonian Institution in Washington to investigate the possibility of establishing an International Center for the Study of Primate Animals. Dr Napier, a leading authority on primate biology, will be trying to plan programmes for the best training of primate biologists on both sides of the Atlantic, and will also be studying primate classification, morphology, anatomy, genetics, palaeontology, ecology and behaviour.

\section{Who Does What}

THe Department of Education and Science and the British Council have produced their guide to Scientific Research in British Universities and Colleges (HMSO. Vol. 1, Physical Sciences, £2; Vol. II, Biological Sciences, £2; Vol. III, Social Sciences, £l 12s. 6d.) at the end of the academic year to which it relates. Although the great value of this publication may be somewhat tarnished by the fact that roughly 10 per cent of those listed in it may have moved to universities other than those to which they are said to be affiliated, or may have changed their research projects, it remains a considerable achievement that this compendium should be published at all. This year, the volumes are somewhat more free from error than is usually the case. The subject index remains wayward, with some coarsely defined categories and some defined in great detail. The character of descriptions of research projects varies enormously from one university to another-some spell out what individual members of a department do and some still include them all under one great umbrella.

The social sciences volume breaks new ground by including among the institutions with which research projects are identified organizations which are not strictly universities at all-the London Transport Board, for example, the Central Office of Information and the Shirley Institute. Apparently the publishers would be prepared to include in this volume details of work carried out in industrial establishments. The future of the other compilations will depend on a survey being carried out by the Office of Scientific and Technical Information. Potential users in universities and government departments have been asked to specify the kinds of enquiries they would like to see made. One possibility is that a magnetic tape index to the volumes will be produced, and that the work of government establishments may be lumped in with that of universities. There seems as yet no prospect that industrial research in the full-blooded sense will be included.

\section{More Plans for Food}

ANother attempt to provide policies for feeding the world population has been made, this time by a committee which advises the Economic and Social Council of the United Nations. The Advisory Committee on the Application of Science and Technology to Development, under whose aegis the report is published, has been advised by a series of sub-committees, expert panels, and working parties, but it seems that responsibility for most of the recommendations rests with a small group of three: Dr W. F. J. Cuthbertson (UK), Dr D. S. Bhatia (India) and Dr A. A. Pokrovsky (USSR).

The committee has concentrated on one aspect of the problem, increasing the production and use of edible protein. Unfortunately it has come up with some rather well worn suggestions. Protein from conventional sources should be increased, using modern technology, and should be supported by better use of marine and inland fisheries. The committee also sees a role for unconventional sources of protein; soya, peanuts, and textured vegetable products are all given a favourable mention. Fish protein concentrate (fish meal) can also contribute, the committee feels, and it recommends greatly intensified research on single cell protein sources, which can be produced without using agricultural land. There are also recommendations about research, training and marketing.

The report will be debated by the Economic and Social Council at its meeting this month, which has in the past been a signal for similar reports to disappear without trace. This time the committee has made a worthwhile attempt to cost its proposals, and some of them are surprisingly modest $-\$ 5$ million annually to prevent waste, for example, or $\$ 5$ to $\$ 8$ million a year over the next five years to set up regional centres for research and training in agricultural technology and food science. One problem which the report ignoresin common with almost all reports of this kind-is the effect of the price structure on food production. Until producers, distributors and retailers can go ahead with full confidence of making profits from their work, nothing is likely to come of the plans. This, perhaps, was what President Johnson's Science Advisory Committee was hinting at in its report on food production (Nature, 215, 234; 1967) when it said that few countries were making full use of the power of the market economy.

\section{Rockefeller against Hunger}

THE Rockefeller Foundation remains dedicated to the problems of food and population in developing countries. According to $\mathrm{Mr} \mathrm{J}$. G. Harrar, the president, in his review of 1966 , out of a total spending of $\$ 31.9$ million on the foundation's five principal areas of interest $\$ 8.6$ million was spent on the programme called 'Towards the Conquest of Hunger' and $\$ 3.8$ 